\title{
SARS-CoV-2 Testing in Florida, Illinois, and Maryland: Access and Barriers
}

Steven J. Clipman ${ }^{1}$, Amy Wesolowski², Shruti H. Mehta², Smisha Agarwal1 ${ }^{1}$, Sarah E. Cobey $^{3}$, Derek A.T. Cummings ${ }^{4}$, Dustin G. Gibson ${ }^{1}$, Alain B. Labrique ${ }^{1,2}$, Gregory D. Kirk $^{2,5}$, Sunil S. Solomon ${ }^{2,5}$

1. Department of International Health, Johns Hopkins Bloomberg School of Public Health, Baltimore, Maryland, United States of America

2. Department of Epidemiology, Johns Hopkins Bloomberg School of Public Health, Baltimore, Maryland, United States of America

3. Department of Ecology and Evolution, University of Chicago, Chicago, Illinois, United States of America

4. Department of Biology and the Emerging Pathogens Institute, University of Florida, Gainesville, Florida, United States of America

5. Department of Medicine, Division of Infectious Diseases, Johns Hopkins University School of Medicine, Baltimore, Maryland, United States of America

Corresponding author:

Sunil Suhas Solomon, MBBS, PhD, MPH

Johns Hopkins University School of Medicine

1830 E. Monument St, Room 444

Baltimore, MD 21287

Phone: 443-287-9596

Email: sss@jhmi.edu 


\section{Abstract}

Objective: To characterize the SARS-CoV-2 testing cascade and associated barriers in three US states.

Methods: We recruited participants from Florida, Illinois, and Maryland ( 1000/state) for an online survey September 16 - October 15, 2020. The survey covered demographics, COVID-19 symptoms, and experiences around SARS-CoV-2 PCR testing in the prior 2 weeks. Logistic regression was used to analyze associations with outcomes of interest. Results: Overall, $316(10 \%)$ of 3,058 respondents wanted/needed a test in the two weeks prior to the survey. Of these, 166 (53\%) were able to get tested and $156(94 \%)$ received results; $53 \%$ waited $\geq 8$ days to get results from when they wanted/needed a test. There were no significant differences by state. Among those wanting/needing a test, getting tested was significantly less common among men (aOR: 0.46) and those reporting black race (aOR: 0.53 ) and more common in those reporting recent travel (aOR: 3.35).

Conclusions: There is an urgent need for a national communication strategy on who should get tested and where one can get tested. Additionally, measures need to be taken to improve access and reduce turn-around-time. 


\section{Introduction}

While there is clear evidence supporting the need for rapid detection and isolation of SARS-CoV-2 infections, ${ }^{1}$ testing access across the US has been uneven, ${ }^{2,3}$ hampered by logistics, supply chain issues, and changing recommendations. ${ }^{4}$ For example, on August 24, 2020, the Centers for Disease Control and Prevention (CDC) recommended that asymptomatic persons not be tested even in the setting of potential exposure but reversed their recommendation on September 18, 2020 to reinforce testing for asymptomatic persons. ${ }^{5}$ In this dynamic context, community-based data on testing uptake and barriers are critical to the public health response. We present the SARSCoV-2 testing cascade and associated barriers across three US states (Florida, Illinois, and Maryland) at varying local epidemic stages in September 2020.

\section{Methods}

\section{Study Setting}

We recruited participants from Florida, Illinois, and Maryland ( 1000/state) for an online survey

from September 16 - October 15, 2020. The survey covered demographics, COVID-19 symptoms, and experiences around SARS-CoV-2 PCR testing in the prior 2 weeks. States were selected to represent the diversity of the pandemic with respect to daily case counts and statewide orders on non-pharmaceutical interventions. At the time of survey, there were no systematic differences in testing across these states ${ }^{5-7}$; all had public and private options including free testing that did not require a doctor's order. Cases counts were stable in Florida ( 2,700 cases/day), rising in Illinois $(\sim 2,400$ cases/day), and decreasing in Maryland ( $\sim 50$ cases). Florida had the fewest restrictions (no restrictions on businesses or a statewide mask mandate), Maryland was fairly open with some restrictions (establishments up to $75 \%$ capacity, statewide mask mandate), and Illinois had many establishments open at 50\% capacity, indoor dining at $25 \%$ capacity, and a statewide mask mandate.

\section{Study Sample}


All participants were $\geq 18$ years, provided consent, and resided in the state. Participants were recruited using Dynata (https://www.dynata.com), one of the largest first-party global data platforms. Dynata maintains a database of potential participants who are randomized to specific surveys if they meet the demographic targets of the survey; additionally, participants can select a survey from a list of potential options (survey topic not provided). Participants receive modest compensation. Security checks and quality verifications include digital fingerprinting and spot checking via third party verification.

In order to accrue demographically representative samples, we provided quotas for age, gender, race/ethnicity, and income based on the population composition of the states. Across states, 5,075 were routed to the survey; 714 did not start the survey, 694 started but did not complete the survey, and 609 responses were excluded for non-eligibility.

\section{Statistical Methods}

Statistical analyses were carried out using Python (v3.7.3) and R (v3.5.1). We restricted the analyses to SARS-CoV-2 PCR testing in the prior two weeks to minimize recall bias and reflect current diagnostic testing access. Residential zip code and the National Center for Health Statistics (NCHS) Urban-Rural classification scheme ${ }^{8}$ were used for urbanrural classification. Chi square and Mann-Whitney tests were used to compare categorical and continuous variables, respectively. Logistic regression was used to analyze associations with two outcomes: 1) self-report of wanting/needing a SARS-CoV-2 test among all sampled; and 2) receiving a test among those who wanted/needed a test. Variables were considered for inclusion in multivariable analyses if they held biologic/epidemiologic significance or were associated in univariable analysis at $p<0.10$; age, gender, race/ethnicity, and state were included regardless of statistical significance. Additional variables considered included: household size, COVID-19 infection in a household member, education, annual household income, employment status (i.e., working outside the home), self-reported exposure and/or symptoms, report of travel, urban-rural classification, and state.

\section{Results}


Of 3,058 persons, $316(10 \%)$ reported wanting/needing a test in the prior two weeks. Median age of participants wanting/needing a test was 36 years and $46 \%$ were female; $47 \%$ self-identified as White and $57 \%$ reported working outside the home (overall sample described in Supplementary Table S1; Figure S2). In multivariable analyses, wanting/needing a test was significantly more common among males and younger respondents, Blacks vs. Whites, and those with symptoms, self-reported exposure or both (all p-values $<0.05$; Supplementary Table S3).

Of 316 who wanted/needed a test in the prior 2 weeks, $166(53 \%)$ were able to get tested, of whom, $156(94 \%)$ received results with no significant differences by state (Supplementary Figure S4). In multivariate analyses, among those wanting/needing a test, getting tested was significantly less common among men (aOR: 0.46; 95\% Cl: 0.26 - 0.82) and those reporting black race (aOR: 0.53; 95\% Cl: $0.28-0.99$ ) and more common in those reporting recent travel (aOR: 3.35; 95\% Cl: $1.79-6.25)$ (Supplementary Table S5).

The primary reasons for testing were desire to know one's status (35\%) and symptoms $(28 \%)$. Among those tested, $53 \%$ had to wait $\geq 8$ days to get a result from when they wanted/needed a test (Table 1). Seventy-one percent reported quarantining while awaiting results. Of 146 who wanted/needed a test, but did not get tested, main reasons were not knowing where to go (36\%) and distance/waiting time (33\%); $21 \%$ reported fear of being tested.

Additionally, 177 (6\%) participants reported symptoms, exposure or both but did not want a test. The main reasons were belief that symptoms were due to other causes $(42 \%)$, no symptoms (18\%), not wanting to know one's status (18\%), and logistic issues, such as not knowing where to go or lack of transportation (15\%).

\section{Discussion}

Of 3,058 participants surveyed, 10\% reported wanting/needing a SARS-CoV-2 test in the prior two weeks, only $53 \%$ of who were able to get tested with no differences by 
state. While it was encouraging that those with symptoms and potential exposure were the most likely to get tested, it is noteworthy that approximately $62 \%$ with potential exposure and/or symptoms did not get tested primarily due to logistic reasons or not knowing where to go. Moreover, among those tested, there were significant delays in accessing a test and receiving results, with over half waiting 8 or more days for results from the time they wanted/needed a test. This delay is considerable compared to estimates of the serial interval $(7.5 \text { days })^{9}$ and generation time ( 5 days $)^{10}$ which have implications for community transmission. Such delays can also complicate efforts to implement contact tracing to control local epidemics and may become more pronounced as cases again surge. Onset of respiratory viruses (e.g., influenza) can further complicate existing diagnostic efforts due to similar presenting symptoms thereby, increasing demand for testing.

There are limitations of online surveys; individuals need internet access to participate and so these surveys may underrepresent lower income/less educated individuals. However, in a constantly evolving pandemic where face-to-face data collection is nearly impossible, this approach allows for the collection of individual-level data across diverse geographies and demographics in a rapid and safe manner. If anything, we are likely overestimating access to testing. Moreover, care was taken to balance targets on state demographic characteristics and estimates of flu vaccine coverage are comparable to samples based on random digit dialing. ${ }^{11}$ Additionally, there is a possibility respondent misclassified the type of test.

Regardless, these data reflecting common testing barriers across three US states clearly underscore the importance of a unified national strategy with clear messaging on who, where, when, and how to get a test. Concurrently, there should be a focus on improved turn-around-time by incorporating newer approaches such as rapid lateral flow assays. 


\section{Acknowledgements}

We would like to gratefully acknowledge Mr. Adebola Adegbesan who worked closely with our team in the recruitment of the study sample.

\section{Author Contributions}

SJC, SSS, and SHM had full access to all the data in the study and take responsibility for the integrity of the data and the accuracy of the data analysis. Concept and design: SJC, AW, SHM, and SSS. Acquisition, analysis, or interpretation of data: All authors. Drafting of the manuscript: SJC, AW, SHM, SSS. Critical revision of the manuscript for important intellectual content: All authors. Statistical analysis: SJC. Obtained funding: SHM, AW. Supervision: SSS.

\section{Conflict of Interest Disclosures}

SHM reports personal fees from Gilead Sciences, outside the submitted work. SSS reports grants/products from Gilead Sciences and grants/products from Abbott Diagnostics, outside the submitted work.

\section{Funding/Support}

This work was supported by the Johns Hopkins COVID-19 Research Response Program. AW is funded by a Career Award at the Scientific Interface by the Burroughs Wellcome Fund and by the National Library of Medicine of the National Institutes of Health (DP2LM013102). SSS is funded by the National Institute on Drug Abuse (DP2DA040244).

\section{Role of the Funder/Sponsor}

The funder had no role in the design and conduct of the study; collection, management, analysis, and interpretation of the data; preparation, review, or approval of the manuscript; and decision to submit the manuscript for publication. The content is solely the responsibility of the authors and does not necessarily represent the official views of the Johns Hopkins University or the National Institutes of Health 


\section{References}

1. Cheng HY, Jian SW, Liu DP, Ng TC, Huang WT, Lin HH. Contact Tracing Assessment of COVID-19 Transmission Dynamics in Taiwan and Risk at Different Exposure Periods Before and After Symptom Onset. JAMA Intern Med. 2020;180(9):1156-1163.

2. Dodds C, Fakoya I. Covid-19: ensuring equality of access to testing for ethnic minorities. Bmj. 2020;369:m2122.

3. Rader B, Astley CM, Sy KTL, et al. Geographic access to United States SARSCoV-2 testing sites highlights healthcare disparities and may bias transmission estimates. J Travel Med. 2020.

4. Centers for Disease Control and Prevention. Overview of Testing for SARS-CoV2 (COVID-19). 2020; https://www.cdc.gov/coronavirus/2019-ncov/hcp/testingoverview.html. Accessed 09/20/2020, 2020.

5. Maryland Department of Health. MD COVID-19 Testing Sites. 2020; https://coronavirus.maryland.gov/datasets/md-covid19-testing-sites. Accessed 09/28/2020.

6. Florida Health. Florida COVID-19 Testing Sites. 2020; https://floridahealthcovid19.gov/testing-sites/. Accessed 09/28/2020.

7. Illinois Department of Public Health. COVID-19 Testing Sites. 2020; https://dph.illinois.gov/testing. Accessed 09/28/2020.

8. Centers for Disease Control and Prevention. NCHS Urban-Rural Classification Scheme for Counties. 2013; https://www.cdc.gov/nchs/data access/urban rural.htm. Accessed 08/01/2020, 2020.

9. Li Q, Guan X, Wu P, et al. Early Transmission Dynamics in Wuhan, China, of Novel Coronavirus-Infected Pneumonia. The New England journal of medicine. 2020;382(13):1199-1207.

10. Ferretti L, Wymant C, Kendall M, et al. Quantifying SARS-CoV-2 transmission suggests epidemic control with digital contact tracing. Science. 2020;368(6491):eabb6936.

11. Clipman SJ, Wesolowski AP, Gibson DG, et al. Rapid real-time tracking of nonpharmaceutical interventions and their association with SARS-CoV-2 positivity: The COVID-19 Pandemic Pulse Study. Clinical Infectious Diseases. 2020. 
medRxiv preprint doi: https://doi.org/10.1101/2020.12.23.20248789; this version posted December 24, 2020. The copyright holder for this preprint (which was not certified by peer review) is the author/funder, who has granted medRxiv a license to display the preprint in perpetuity.

It is made available under a CC-BY-NC-ND 4.0 International license .

\section{Table}

Table 1. Demographics, barriers to testing, and wait times among persons who reported wanting/needing a SARS-CoV-2 PCR test in the prior 2 weeks across FL, IL, and MD.

\begin{tabular}{|c|c|c|c|c|}
\hline & Total & FL & IL & MD \\
\hline Wanted/Needed a Test & $n=316$ & $n=104$ & $n=116$ & $n=96$ \\
\hline Median Age (IQR) & $36(27-50)$ & $37(29-49)$ & $35(25-50)$ & $37(28-53)$ \\
\hline Median Household Size (IQR) & $2(2-3)$ & $3(2-4)$ & $2(1-3)$ & $2(2-3)$ \\
\hline \multicolumn{5}{|l|}{ Gender, n (\%) } \\
\hline Female & $144(46 \%)$ & $42(40 \%)$ & $62(53 \%)$ & $40(42 \%)$ \\
\hline Male & $170(54 \%)$ & $61(60 \%)$ & $54(47 \%)$ & $55(57 \%)$ \\
\hline \multicolumn{5}{|l|}{ Race/Ethnicity, n (\%) } \\
\hline White/Caucasian & $147(47 \%)$ & $44(42 \%)$ & $55(47 \%)$ & $48(50 \%)$ \\
\hline Black/African American & $96(30 \%)$ & $33(32 \%)$ & $28(24 \%)$ & $35(37 \%)$ \\
\hline Hispanic/Latino & $49(16 \%)$ & $20(19 \%)$ & $25(22 \%)$ & $4(4 \%)$ \\
\hline Asian/Pacific Islander & $16(5 \%)$ & $3(3 \%)$ & $5(4 \%)$ & $8(8 \%)$ \\
\hline Other & $8(2 \%)$ & $4(4 \%)$ & $3(3 \%)$ & $1(1 \%)$ \\
\hline \multicolumn{5}{|l|}{ Educational Attainment, $\mathbf{n}(\%)$} \\
\hline High school degree or less & $53(17 \%)$ & $20(19 \%)$ & $19(16 \%)$ & $14(15 \%)$ \\
\hline Associate degree & $51(33 \%)$ & $12(12 \%)$ & $21(18 \%)$ & $18(19 \%)$ \\
\hline Some college (no degree) & $35(44 \%)$ & $11(11 \%)$ & $19(16 \%)$ & $5(5 \%)$ \\
\hline Bachelor's degree & $97(75 \%)$ & $26(25 \%)$ & $37(32 \%)$ & $34(35 \%)$ \\
\hline Graduate degree & $79(25 \%)$ & $34(33 \%)$ & $20(17 \%)$ & $25(26 \%)$ \\
\hline \multicolumn{5}{|l|}{ Annual Household Income, n (\%) } \\
\hline$<\$ 20,000$ & $43(14 \%)$ & $20(19 \%)$ & $15(13 \%)$ & $8(8 \%)$ \\
\hline$\$ 20,000-\$ 39,000$ & $59(19 \%)$ & $17(16 \%)$ & $28(24 \%)$ & $14(15 \%)$ \\
\hline$\$ 40,000-\$ 49,000$ & $16(4 \%)$ & $5(5 \%)$ & $10(9 \%)$ & $1(1 \%)$ \\
\hline$\$ 50,000-\$ 69,000$ & $44(14 \%)$ & $16(15 \%)$ & $17(15 \%)$ & $11(12 \%)$ \\
\hline$\$ 70,000+$ & $154(49 \%)$ & $46(44 \%)$ & $46(40 \%)$ & $62(65 \%)$ \\
\hline \multicolumn{5}{|l|}{ Employment Status, $\mathbf{n}(\%)$} \\
\hline Employed, working outside the home & $177(56 \%)$ & $64(62 \%)$ & $52(64 \%)$ & $61(64 \%)$ \\
\hline Employed, working from home & $85(27 \%)$ & $28(27 \%)$ & $39(34 \%)$ & $18(19 \%)$ \\
\hline Unemployed & $21(7 \%)$ & $2(2 \%)$ & $13(11 \%)$ & $6(6 \%)$ \\
\hline Retired & $30(10 \%)$ & $9(19 \%)$ & $11(10 \%)$ & $10(11 \%)$ \\
\hline \multicolumn{5}{|l|}{ Urban-Rural Classification } \\
\hline Urban & $133(42 \%)$ & $51(49 \%)$ & $64(55 \%)$ & $18(19 \%)$ \\
\hline Suburban & $154(49 \%)$ & $49(47 \%)$ & $28(24 \%)$ & $77(80 \%)$ \\
\hline Rural & $29(9 \%)$ & $4(4 \%)$ & $24(21 \%)$ & $1(1 \%)$ \\
\hline Reported Travel for Any Purpose, $\mathbf{n}(\%)$ & $111(35 \%)$ & $49(47 \%)$ & $29(25 \%)$ & $33(34 \%)$ \\
\hline Unable to Get Tested & $n=146$ & $n=44$ & $n=63$ & $n=39$ \\
\hline \multicolumn{5}{|l|}{ Reasons for Not Getting Tested } \\
\hline Did not know where to go & $52(36 \%)$ & $13(30 \%)$ & $24(38 \%)$ & $15(38 \%)$ \\
\hline
\end{tabular}


medRxiv preprint doi: https://doi.org/10.1101/2020.12.23.20248789; this version posted December 24, 2020. The copyright holder for this preprint (which was not certified by peer review) is the author/funder, who has granted medRxiv a license to display the preprint in perpetuity.

It is made available under a CC-BY-NC-ND 4.0 International license .

\begin{tabular}{|c|c|c|c|c|}
\hline Could not get an order from a doctor & $31(21 \%)$ & $5(11 \%)$ & $15(24 \%)$ & $11(28 \%)$ \\
\hline Testing center too far away & $30(21 \%)$ & $14(32 \%)$ & $10(16 \%)$ & $6(15 \%)$ \\
\hline Afraid to get tested & $31(21 \%)$ & $15(34 \%)$ & $8(13 \%)$ & $8(21 \%)$ \\
\hline Too long of a line to get tested & $17(12 \%)$ & $6(14 \%)$ & $5(8 \%)$ & $6(15 \%)$ \\
\hline Language barriers & $7(5 \%)$ & $4(9 \%)$ & $0(0 \%)$ & $3(8 \%)$ \\
\hline No Reason Specified & $8(5 \%)$ & $2(5 \%)$ & $4(6 \%)$ & $2(5 \%)$ \\
\hline Got Tested & $n=166$ & $\mathbf{n}=\mathbf{5 8}$ & $\mathbf{n}=\mathbf{5 1}$ & $\mathrm{n}=\mathbf{5 7}$ \\
\hline \multicolumn{5}{|c|}{ Time from Wanting/Needing Test to Getting Tested } \\
\hline Same day & $52(31 \%)$ & $18(31 \%)$ & $18(35 \%)$ & $16(28 \%)$ \\
\hline $1-2$ days & $21(13 \%)$ & $12(21 \%)$ & $3(6 \%)$ & $6(11 \%)$ \\
\hline $3-5$ days & $51(31 \%)$ & $13(22 \%)$ & $16(31 \%)$ & $22(39 \%)$ \\
\hline $6-7$ days & $21(13 \%)$ & $7(12 \%)$ & $7(14 \%)$ & $7(12 \%)$ \\
\hline More than 1 week & $13(8 \%)$ & $6(10 \%)$ & $4(8 \%)$ & $3(5 \%)$ \\
\hline Received Result by Time of Survey & $n=156$ & $n=55$ & $n=48$ & $n=53$ \\
\hline \multicolumn{5}{|l|}{ Time from Testing to Receiving Results } \\
\hline Same day & $27(17 \%)$ & $15(27 \%)$ & $7(15 \%)$ & $5(9 \%)$ \\
\hline $1-2$ days & $22(14 \%)$ & $9(17 \%)$ & $5(11 \%)$ & $8(15 \%)$ \\
\hline $3-5$ days & $56(36 \%)$ & $13(24 \%)$ & $19(40 \%)$ & $24(45 \%)$ \\
\hline $6-7$ days & $30(19 \%)$ & $9(17 \%)$ & $11(23 \%)$ & $10(19 \%)$ \\
\hline More than 1 week & $19(12 \%)$ & $8(15 \%)$ & $5(11 \%)$ & $6(11 \%)$ \\
\hline $\begin{array}{l}\text { Time from Wanting/Needing a Test to } \\
\text { Receiving Results }\end{array}$ & $n=151$ & $n=53$ & $n=45$ & $n=53$ \\
\hline Same day & $16(11 \%)$ & $8(15 \%)$ & $5(11 \%)$ & $3(6 \%)$ \\
\hline $1-2$ days & $14(9 \%)$ & $7(13 \%)$ & $2(4 \%)$ & $5(9 \%)$ \\
\hline $3-5$ days & $35(23 \%)$ & $13(25 \%)$ & $12(27 \%)$ & $10(19 \%)$ \\
\hline $6-7$ days & $6(4 \%)$ & $4(8 \%)$ & $1(2 \%)$ & $1(2 \%)$ \\
\hline More than 1 week & $80(53 \%)$ & $21(40 \%)$ & $25(56 \%)$ & $34(64 \%)$ \\
\hline
\end{tabular}

Note: Numbers may not sum to the total if there were participants who elected not to answer a given question. 
medRxiv preprint doi: https://doi.org/10.1101/2020.12.23.20248789; this version posted December 24, 2020. The copyright holder for this preprint (which was not certified by peer review) is the author/funder, who has granted medRxiv a license to display the preprint in perpetuity.

It is made available under a CC-BY-NC-ND 4.0 International license .

\section{Supplemental Material}

Table S1. Characteristics of overall study sample by state.

\begin{tabular}{|c|c|c|c|c|}
\hline & Total & FL & IL & MD \\
\hline & $n=3,058$ & $n=998$ & $n=1,045$ & $n=1,015$ \\
\hline Median Age (IQR) & $47(33-64)$ & $48(33-65)$ & $47(35-64)$ & $46(32-63)$ \\
\hline Median Household Size (IQR) & $2(2-3)$ & $2(2-3)$ & $2(1-3)$ & $2(2-3)$ \\
\hline \multicolumn{5}{|l|}{ Gender, n (\%) } \\
\hline Female & $1,612(53 \%)$ & $537(51 \%)$ & $545(52 \%)$ & $477(53 \%)$ \\
\hline Male & $1,431(47 \%)$ & $505(49 \%)$ & $502(48 \%)$ & $422(47 \%)$ \\
\hline Other & $1(0.03 \%)$ & $0(0 \%)$ & $0(0 \%)$ & $1(0.1 \%)$ \\
\hline \multicolumn{5}{|l|}{ Race/Ethnicity, n (\%) } \\
\hline White/Caucasian & $1,712(56 \%)$ & $444(45 \%)$ & $628(61 \%)$ & $640(64 \%)$ \\
\hline Black/African American & $632(21 \%)$ & $223(22 \%)$ & $169(16 \%)$ & $240(24 \%)$ \\
\hline Hispanic/Latino & $437(14 \%)$ & $241(24 \%)$ & $141(14 \%)$ & $55(5 \%)$ \\
\hline Asian/Pacific Islander & $175(6 \%)$ & $58(6 \%)$ & $65(6 \%)$ & $52(5 \%)$ \\
\hline Other & $75(3 \%)$ & $25(3 \%)$ & $33(3 \%)$ & $17(2 \%)$ \\
\hline \multicolumn{5}{|l|}{ Educational Attainment, n (\%) } \\
\hline High school degree or less & $552(18 \%)$ & $181(18 \%)$ & $192(18 \%)$ & $179(18 \%)$ \\
\hline Associate degree & $544(18 \%)$ & $167(17 \%)$ & $207(20 \%)$ & $170(17 \%)$ \\
\hline Some college (no degree) & $335(11 \%)$ & $133(13 \%)$ & $122(12 \%)$ & $80(8 \%)$ \\
\hline Bachelor's degree & $935(31 \%)$ & $299(30 \%)$ & $320(31 \%)$ & $316(31 \%)$ \\
\hline Graduate degree & $672(22 \%)$ & $213(22 \%)$ & $198(19 \%)$ & $261(26 \%)$ \\
\hline \multicolumn{5}{|l|}{ Annual Household Income, $\mathrm{n}(\%)$} \\
\hline$<\$ 20,000$ & $336(11 \%)$ & $134(13 \%)$ & $101(10 \%)$ & $101(10 \%)$ \\
\hline$\$ 20,000-\$ 39,000$ & $481(16 \%)$ & $194(19 \%)$ & $169(16 \%)$ & $118(12 \%)$ \\
\hline$\$ 40,000-\$ 49,000$ & $250(8 \%)$ & $103(10 \%)$ & $82(8 \%)$ & $65(6 \%)$ \\
\hline$\$ 50,000-\$ 69,000$ & $548(18 \%)$ & $171(17 \%)$ & $215(21 \%)$ & $162(16 \%)$ \\
\hline$\$ 70,000+$ & $1,443(47 \%)$ & $396(40 \%)$ & $478(46 \%)$ & $569(56 \%)$ \\
\hline \multicolumn{5}{|l|}{ Employment Status, n (\%) } \\
\hline Employed, working outside the home & $1,168(37 \%)$ & $361(37 \%)$ & $427(41 \%)$ & $380(38 \%)$ \\
\hline Employed, working from home & $878(29 \%)$ & $275(28 \%)$ & $299(29 \%)$ & $304(30 \%)$ \\
\hline Unemployed & $309(10 \%)$ & $102(10 \%)$ & $110(11 \%)$ & $97(10 \%)$ \\
\hline Retired & $664(22 \%)$ & $245(25 \%)$ & $199(19 \%)$ & $220(22 \%)$ \\
\hline \multicolumn{5}{|l|}{ Urban-Rural Classification } \\
\hline Urban & $1,018(33 \%)$ & $433(43 \%)$ & $486(47 \%)$ & $99(10 \%)$ \\
\hline Suburban & $1,764(58 \%)$ & $511(51 \%)$ & $385(37 \%)$ & $868(86 \%)$ \\
\hline Rural & $276(9 \%)$ & $54(5 \%)$ & $174(17 \%)$ & $48(5 \%)$ \\
\hline Reported Exposure, n (\%) & $235(8 \%)$ & $98(10 \%)$ & $79(8 \%)$ & $58(6 \%)$ \\
\hline Reported Symptoms, n (\%) & $223(7 \%)$ & $92(9 \%)$ & $71(7 \%)$ & $60(6 \%)$ \\
\hline Reported Travel for Any Purpose, $\mathbf{n}(\%)$ & $494(16 \%)$ & $184(18 \%)$ & $142(14 \%)$ & $168(17 \%)$ \\
\hline
\end{tabular}

Note: Numbers may not sum to the total if there were participants who elected not to answer a given question. 
medRxiv preprint doi: https://doi.org/10.1101/2020.12.23.20248789; this version posted December 24, 2020. The copyright holder for this preprint (which was not certified by peer review) is the author/funder, who has granted medRxiv a license to display the preprint in perpetuity.

It is made available under a CC-BY-NC-ND 4.0 International license .
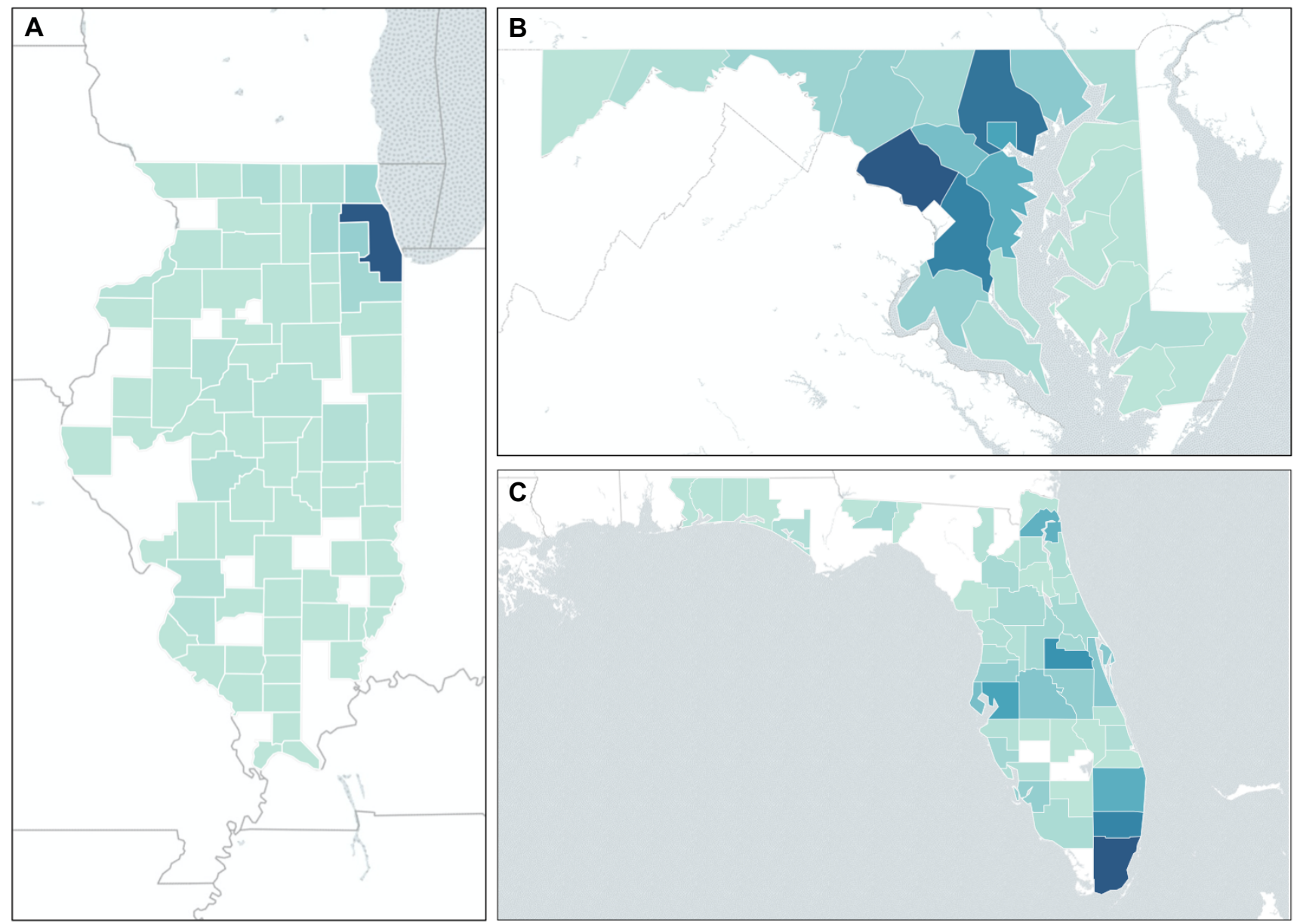

Fig S2. Distribution of study sample by county in each of the four study states: (A) Illinois, (B) Maryland, and (C) Florida. Darker shaded polygons represent a higher proportion of respondents. 
medRxiv preprint doi: https://doi.org/10.1101/2020.12.23.20248789; this version posted December 24, 2020. The copyright holder for this preprint (which was not certified by peer review) is the author/funder, who has granted medRxiv a license to display the preprint in perpetuity.

It is made available under a CC-BY-NC-ND 4.0 International license .

Table S3. Factors associated with wanting/needing a SARS-CoV-2 PCR test in the prior 2 weeks $(n=3,058)$. Results from univariable and multivariable regression analysis.

\begin{tabular}{|c|c|c|c|c|}
\hline Variable & $\begin{array}{l}\text { Unadjusted } \\
\text { Odds Ratio }\end{array}$ & $\begin{array}{c}95 \% \\
\begin{array}{c}\text { Confidence } \\
\text { Interval }\end{array}\end{array}$ & $\begin{array}{l}\text { Adjusted } \\
\text { Odds Ratio }\end{array}$ & $\begin{array}{c}95 \% \\
\text { Confidence } \\
\text { Interval }\end{array}$ \\
\hline Age (per 5-year increase) & 0.84 & $0.81-0.87$ & 0.98 & $0.88-0.98$ \\
\hline Household Size (per 1-person increase) & 1.10 & $1.01-1.19$ & - & - \\
\hline $\begin{array}{l}\text { Positive Household Member } \\
\text { (in the prior } 2 \text { weeks) }\end{array}$ & 11.04 & $7.93-15.4$ & - & - \\
\hline \multicolumn{5}{|l|}{ Gender } \\
\hline Female (ref.) & - & - & - & - \\
\hline Male & 1.37 & $1.09-1.74$ & 1.52 & $1.14-2.04$ \\
\hline \multicolumn{5}{|l|}{ Race/Ethnicity } \\
\hline White (ref.) & - & - & - & - \\
\hline Black/African American & 1.93 & $1.47-2.54$ & 1.85 & $1.29-2.67$ \\
\hline Hispanic/Latino & 1.35 & $0.96-1.91$ & 1.34 & $0.86-2.07$ \\
\hline Asian/Pacific Islander & 1.07 & $0.62-1.84$ & 1.30 & $0.70-2.42$ \\
\hline Other & 1.32 & $0.62-2.81$ & 1.61 & $0.68-3.79$ \\
\hline \multicolumn{5}{|l|}{ Educational Attainment } \\
\hline High school degree or less (ref.) & - & - & - & - \\
\hline Associate degree & 0.97 & $0.65-1.46$ & - & - \\
\hline Some college (no degree) & 1.09 & $0.70-1.72$ & - & - \\
\hline Bachelor's degree & 1.08 & $0.76-1.54$ & - & - \\
\hline Graduate degree & 1.24 & $0.86-1.79$ & - & - \\
\hline \multicolumn{5}{|l|}{ Annual Household Income } \\
\hline$<\$ 20,000$ (ref.) & - & - & - & - \\
\hline$\$ 20,000-\$ 39,000$ & 0.93 & $0.61-1.41$ & - & - \\
\hline$\$ 40,000-\$ 49,000$ & 0.45 & $0.25-0.83$ & - & - \\
\hline$\$ 50,000-\$ 69,000$ & 0.58 & $0.37-0.90$ & - & - \\
\hline$\$ 70,000+$ & 0.80 & $0.56-1.15$ & - & - \\
\hline \multicolumn{5}{|l|}{ Employment Status } \\
\hline Working Outside the Home (ref.) & - & - & - & - \\
\hline Working from Home & 0.60 & $0.46-0.79$ & 0.91 & $0.65-1.27$ \\
\hline Unemployed & 0.41 & $0.26-0.66$ & 0.53 & $0.30-0.92$ \\
\hline Retired & 0.26 & $0.18-0.39$ & 0.91 & $0.53-1.56$ \\
\hline \multicolumn{5}{|l|}{ Urban-Rural Classification } \\
\hline Urban (ref.) & - & - & - & - \\
\hline Suburban & 0.63 & $0.49-0.81$ & 0.79 & $0.57-1.10$ \\
\hline Rural & 0.77 & $0.50-1.18$ & 0.79 & $0.45-1.37$ \\
\hline \multicolumn{5}{|l|}{ State } \\
\hline FL (ref.) & - & - & - & - \\
\hline $\mathrm{IL}$ & 1.07 & $0.81-1.41$ & 1.49 & $1.04-2.14$ \\
\hline MD & 0.89 & $0.67-1.20$ & 1.40 & $0.95-2.06$ \\
\hline \multicolumn{5}{|l|}{ Report Exposure and/or Symptoms } \\
\hline No exposure or symptoms (ref.) & - & - & - & - \\
\hline Exposure only & 10.5 & $7.07-15.6$ & 8.27 & $5.45-12.6$ \\
\hline Symptoms only & 12.2 & $8.10-18.4$ & 10.1 & $6.48-15.7$ \\
\hline Exposure and symptoms & 64.2 & $38.7-106$ & 53.2 & $30.7-92.1$ \\
\hline Report Travel for Any Purpose & 3.29 & $2.55-4.24$ & 1.34 & $0.95-1.90$ \\
\hline
\end{tabular}


medRxiv preprint doi: https://doi.org/10.1101/2020.12.23.20248789; this version posted December 24, 2020. The copyright holder for this preprint (which was not certified by peer review) is the author/funder, who has granted medRxiv a license to display the preprint in perpetuity.

It is made available under a CC-BY-NC-ND 4.0 International license .

A

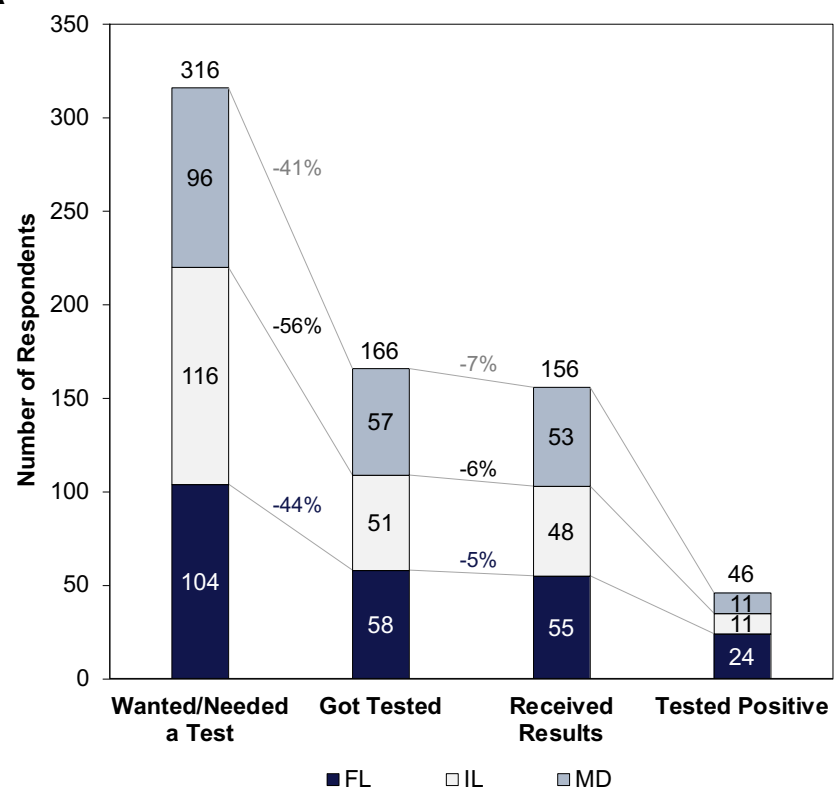

B

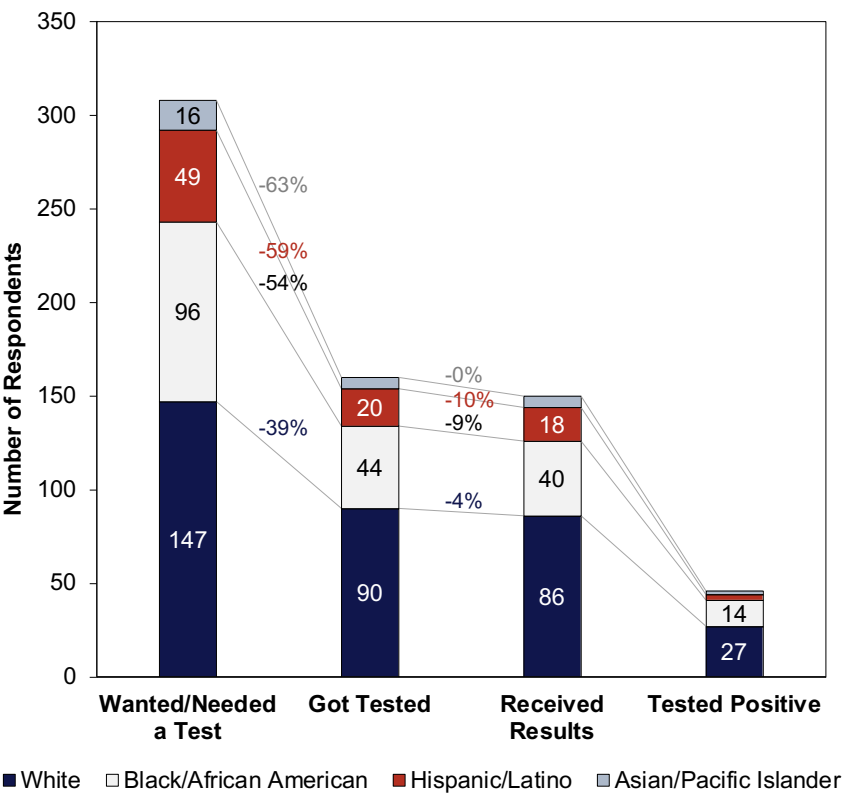

C

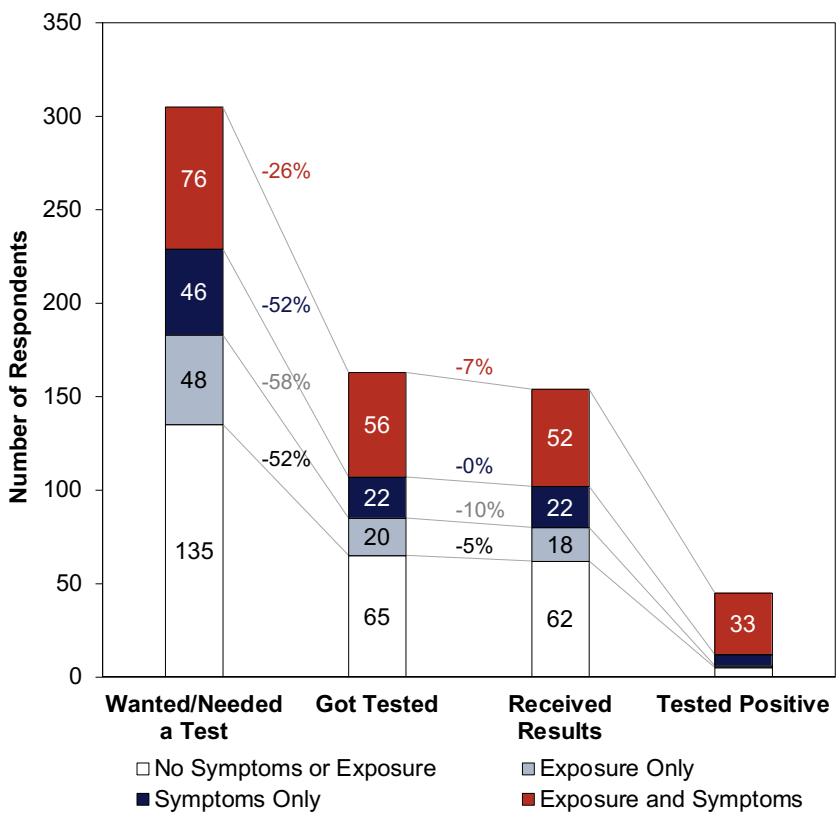

Figure S4. SARS-CoV-2 testing cascade by (A) state, $(B)$ race/ethnicity, and (C) self-reported symptoms. Trend lines and percentages reflect the proportion lost between each step in the cascade.

Note: Numbers may not sum to the total if there were participants who elected not to answer a given question. 
medRxiv preprint doi: https://doi.org/10.1101/2020.12.23.20248789; this version posted December 24, 2020. The copyright holder for this preprint (which was not certified by peer review) is the author/funder, who has granted medRxiv a license to display the preprint in perpetuity.

It is made available under a CC-BY-NC-ND 4.0 International license .

Table S5. Factors associated with getting a PCR test for SARS-CoV-2 among those who wanted/needed a test in the prior 2 weeks $(n=316)$. Results from univariable and multivariable logistic regression analysis.

\begin{tabular}{|c|c|c|c|c|}
\hline Variable & $\begin{array}{l}\text { Unadjusted } \\
\text { Odds Ratio }\end{array}$ & $\begin{array}{c}95 \% \\
\text { Confidence } \\
\text { Interval }\end{array}$ & $\begin{array}{l}\text { Adjusted } \\
\text { Odds Ratio }\end{array}$ & $\begin{array}{c}95 \% \\
\text { Confidence } \\
\text { Interval }\end{array}$ \\
\hline Age (per 5-year increase) & 1.00 & $0.94-1.08$ & 1.00 & $0.90-1.10$ \\
\hline Household Size (per 1-person increase) & 0.99 & $0.85-1.14$ & - & - \\
\hline $\begin{array}{l}\text { Positive Household Member } \\
\text { (in the prior } 2 \text { weeks) }\end{array}$ & 3.13 & $1.79-5.50$ & - & - \\
\hline \multicolumn{5}{|l|}{ Gender } \\
\hline Female (ref.) & - & - & - & - \\
\hline Male & 0.93 & $0.59-1.45$ & 0.46 & $0.26-0.82$ \\
\hline \multicolumn{5}{|l|}{ Race/Ethnicity } \\
\hline White (ref.) & - & - & - & - \\
\hline Black/African American & 0.56 & $0.33-0.94$ & 0.53 & $0.28-0.99$ \\
\hline Hispanic/Latino & 0.45 & $0.23-0.88$ & 0.60 & $0.28-1.28$ \\
\hline Asian/Pacific Islander & 0.42 & $0.14-1.25$ & 0.34 & $0.10-1.13$ \\
\hline Other & 1.90 & $0.37-9.74$ & 2.37 & $0.35-16.2$ \\
\hline \multicolumn{5}{|l|}{ Educational Attainment } \\
\hline High school degree or less (ref.) & - & - & - & - \\
\hline Associate degree & 0.89 & $0.56-1.41$ & - & - \\
\hline Some college (no degree) & 1.11 & $0.67-1.83$ & - & - \\
\hline Bachelor's degree & 1.36 & $0.93-2.00$ & - & - \\
\hline Graduate degree & 1.58 & $1.06-2.34$ & - & - \\
\hline \multicolumn{5}{|l|}{ Annual Household Income } \\
\hline$<\$ 20,000$ (ref.) & - & - & - & - \\
\hline$\$ 20,000-\$ 39,000$ & 0.70 & $0.32-1.56$ & - & - \\
\hline$\$ 40,000-\$ 49,000$ & 0.66 & $0.20-2.15$ & - & - \\
\hline$\$ 50,000-\$ 69,000$ & 0.43 & $0.18-1.02$ & - & - \\
\hline$\$ 70,000+$ & 1.10 & $0.55-2.20$ & - & - \\
\hline \multicolumn{5}{|l|}{ Employment Status } \\
\hline Working Outside the Home (ref.) & - & - & - & - \\
\hline Working from Home & 0.51 & $0.30-0.86$ & 1.54 & $0.83-2.85$ \\
\hline Unemployed & 0.25 & $0.09-0.68$ & 0.36 & $0.11-1.22$ \\
\hline Retired & 0.55 & $0.25-1.20$ & 1.27 & $0.43-3.69$ \\
\hline \multicolumn{5}{|l|}{ Urban-Rural Classification } \\
\hline Urban (ref.) & - & - & - & - \\
\hline Suburban & 1.22 & $0.76-1.95$ & 0.68 & $0.37-1.23$ \\
\hline Rural & 1.42 & $0.63-3.20$ & 1.72 & $0.64-4.60$ \\
\hline \multicolumn{5}{|l|}{ State } \\
\hline FL (ref.) & - & - & - & - \\
\hline $\mathrm{IL}$ & 0.61 & $0.36-1.05$ & 0.75 & $0.38-1.46$ \\
\hline $\mathrm{MD}$ & 1.11 & $0.63-1.95$ & 1.64 & $0.82-3.30$ \\
\hline \multicolumn{5}{|l|}{ Report Exposure and/or Symptoms } \\
\hline No exposure or symptoms (ref.) & - & - & - & - \\
\hline Exposure only & 0.75 & $0.38-1.46$ & 0.66 & $0.31-1.38$ \\
\hline Symptoms only & 0.96 & $0.49-1.88$ & 0.70 & $0.32-1.49$ \\
\hline Exposure and symptoms & 3.08 & $1.66-5.74$ & 1.84 & $0.90-3.79$ \\
\hline Report Travel for Any Purpose & 3.66 & $2.20-6.09$ & 3.35 & $1.79-6.25$ \\
\hline
\end{tabular}


medRxiv preprint doi: https://doi.org/10.1101/2020.12.23.20248789; this version posted December 24, 2020. The copyright holder for this preprint (which was not certified by peer review) is the author/funder, who has granted medRxiv a license to display the preprint in perpetuity.

It is made available under a CC-BY-NC-ND 4.0 International license .

Table S6. Barriers to testing by symptoms among persons who reported wanting/needing a SARS-CoV-2 PCR test in the prior 2 weeks across FL, IL, and MD.

\begin{tabular}{|c|c|c|c|}
\hline & Total & No Symptoms & Any Symptoms \\
\hline Unable to Get Tested & $n=146$ & $n=99$ & $n=45$ \\
\hline \multicolumn{4}{|l|}{ Reasons for Not Getting Tested } \\
\hline Did not know where to go & $52(36 \%)$ & $31(31 \%)$ & $20(44 \%)$ \\
\hline Too long of a line to get tested & $17(12 \%)$ & $12(112 \%)$ & $5(11 \%)$ \\
\hline Could not get an order from a doctor & $31(21 \%)$ & $19(19 \%)$ & $12(27 \%)$ \\
\hline Testing center too far away & $31(21 \%)$ & $24(24 \%)$ & $7(16 \%)$ \\
\hline Afraid to get tested & $30(21 \%)$ & $17(17 \%)$ & $13(29 \%)$ \\
\hline Language barriers & $7(5 \%)$ & $3(3 \%)$ & $4(9 \%)$ \\
\hline
\end{tabular}

